University of Nebraska - Lincoln

DigitalCommons@University of Nebraska - Lincoln

\title{
Influence of Calcium on Microbial Reduction of Solid Phase Uranium(VI)
}

Chongxuan Liu

Pacific Northwest National Laboratory, chongxuan.liu@pnl.gov

Byong-Hun Jeon

Yonsei University

John M. Zachara

Pacific Northwest National Laboratory, john.zachara@pnl.gov

Zheming Wang

Pacific Northwest National Laboratory

Follow this and additional works at: https://digitalcommons.unl.edu/usdoepub

Part of the Bioresource and Agricultural Engineering Commons

Liu, Chongxuan; Jeon, Byong-Hun; Zachara, John M.; and Wang, Zheming, "Influence of Calcium on Microbial Reduction of Solid Phase Uranium(VI)" (2007). US Department of Energy Publications. 186. https://digitalcommons.unl.edu/usdoepub/186

This Article is brought to you for free and open access by the U.S. Department of Energy at DigitalCommons@University of Nebraska - Lincoln. It has been accepted for inclusion in US Department of Energy Publications by an authorized administrator of DigitalCommons@University of Nebraska - Lincoln. 


\title{
Influence of Calcium on Microbial Reduction of Solid Phase Uranium(VI)
}

\author{
Chongxuan Liu, ${ }^{1}$ Byong-Hun Jeon, ${ }^{2}$ John M. Zachara, ${ }^{1}$ Zheming Wang ${ }^{1}$ \\ ${ }^{\text {P}}$ Pacific Northwest National Laboratory, Richland, Washington 99352; \\ telephone: 509-376-0129; fax: 509-376-3650; e-mail: Chongxuan.liu@pnl.gov \\ ${ }^{2}$ Yonsei University, Wonju, Kangwon-Do 220-710, Korea \\ Received 17 October 2006; accepted 16 January 2007 \\ Published online 1 February 2007 in Wiley InterScience (www.interscience.wiley.com). DOI 10.1002/bit.21357
}

ABSTRACT: The effect of calcium on the dissolution and microbial reduction of a representative solid phase uranyl $[\mathrm{U}(\mathrm{VI})]$, sodium boltwoodite $\left(\mathrm{NaUO}_{2} \mathrm{SiO}_{3} \mathrm{OH} \cdot 1.5 \mathrm{H}_{2} \mathrm{O}\right)$, was investigated to evaluate the rate-limiting step of microbial reduction of the solid phase U(VI). Microbial reduction experiments were performed in a culture of a dissimilatory metal-reducing bacterium (DMRB), Shewanella oneidensis strain MR-1, in a bicarbonate medium with lactate as electron donor at $\mathrm{pH} 6.8$ buffered with PIPES. Calcium increased the rate of Na-boltwoodite dissolution and U(VI) bioavailability by increasing its solubility through the formation of a ternary aqueous calcium-uranyl-carbonate species. The ternary species, however, decreased the rates of microbial reduction of aqueous U(VI). Laser-induced fluorescence spectroscopy (LIFS) and transmission electron microscopy (TEM) collectively revealed that microbial reduction of solid phase $\mathrm{U}(\mathrm{VI})$ was a sequentially coupled process of Na-boltwoodite dissolution, $\mathrm{U}(\mathrm{VI})$ aqueous speciation, and microbial reduction of dissolved $\mathrm{U}(\mathrm{VI})$ to $\mathrm{U}(\mathrm{IV})$ that accumulated on bacterial surfaces/periplasm. Under studied experimental conditions, the overall rate of microbial reduction of solid phase $\mathrm{U}(\mathrm{VI})$ was limited by $\mathrm{U}(\mathrm{VI})$ dissolution reactions in solutions without calcium and limited by microbial reduction in solutions with calcium. Generally, the overall rate of microbial reduction of solid phase $\mathrm{U}(\mathrm{VI})$ was determined by the coupling of solid phase $\mathrm{U}(\mathrm{VI})$ dissolution, $\mathrm{U}(\mathrm{VI})$ aqueous speciation, and microbial reduction of dissolved $\mathrm{U}(\mathrm{VI})$ that were all affected by calcium.

Biotechnol. Bioeng. 2007;97: 1415-1422.

(C) 2007 Wiley Periodicals, Inc.

KEYWORDS: microbial reduction; dissolution; uranium; speciation; coupled models; immobilization

\section{Introduction}

In situ immobilization of uranium by microbial reduction of $\mathrm{U}(\mathrm{VI})$ to sparely soluble $\mathrm{U}(\mathrm{IV})$ precipitates is a potential strategy for preventing migration of uranium plumes in subsurface sediments. U(VI) exists as aqueous (mobile) and sorbed/precipitated (immobile) phases in sediments and their relative concentrations are governed by equilibrium and/or kinetic reactions of sorption/desorption and precipitation/dissolution. Aqueous U(VI) can be reduced by dissimilatory metal reducing bacteria (DMRB) under anoxic conditions and reduced $U$ subsequently precipitates as uraninite $\left[\mathrm{UO}_{2}(\mathrm{~s})\right]$ (e.g., Abdelouas et al., 1998; Finneran et al., 2002; Lovley et al., 1991). The bioreduction process decreases aqueous $\mathrm{U}(\mathrm{VI})$ concentration and drives additional release of $U(V I)$ from sorbed/precipitated to aqueous phase by thermodynamic equilibrium gradient. The aqueous $\mathrm{U}(\mathrm{VI})$ concentration is therefore controlled by the coupling of U(VI) geochemistry and microbial activity.

Calcium is a common ion in groundwater that can complex with $\mathrm{U}(\mathrm{VI})$ in bicarbonate solutions to form a ternary calcium-uranyl-carbonate species $\left[\mathrm{Ca}_{2} \mathrm{UO}_{2}\left(\mathrm{CO}_{3}\right)_{3}\right.$ (aq)] (Bernhard et al., 1996, 2001; Kalmykov and Choppin, 2000). Recent studies indicated that bioreduction of U(VI) by DMRB was inhibited when aqueous $\mathrm{U}(\mathrm{VI})$ was dominated by species $\mathrm{Ca}_{2} \mathrm{UO}_{2}\left(\mathrm{CO}_{3}\right)_{3}(\mathrm{aq})$ (Brooks et al., 2003). The $\mathrm{U}(\mathrm{VI})$ bioreduction rates in $\mathrm{Ca}_{2} \mathrm{UO}_{2}\left(\mathrm{CO}_{3}\right)_{3}(\mathrm{aq})$ dominated solutions followed the same Monod-type kinetics as in solutions without calcium, but the rate constant decreased about two orders of magnitude (Liu et al., 2006a). The effect of calcium on microbial reduction of solid phase U(VI) may be more complicated. Equilibrium speciation calculations suggest that calcium may increase the solubility of solid phase U(VI) (Fig. 1a) at circumneutral to alkaline $\mathrm{pH}$, resulting from the effect of calcium on $\mathrm{U}(\mathrm{VI})$ aqueous speciation (Fig. $1 \mathrm{~b}$ and $\mathrm{c}$ ). The increase of the solubility may increase the bioavailability of solid phase $\mathrm{U}(\mathrm{VI})$ as suggested by a recent study showing that solid phase $\mathrm{U}(\mathrm{VI})$ has to dissolve before it is bioavailable for microbial reduction (Liu et al., 2006a). The solubility

\section{(\$) WILEY}



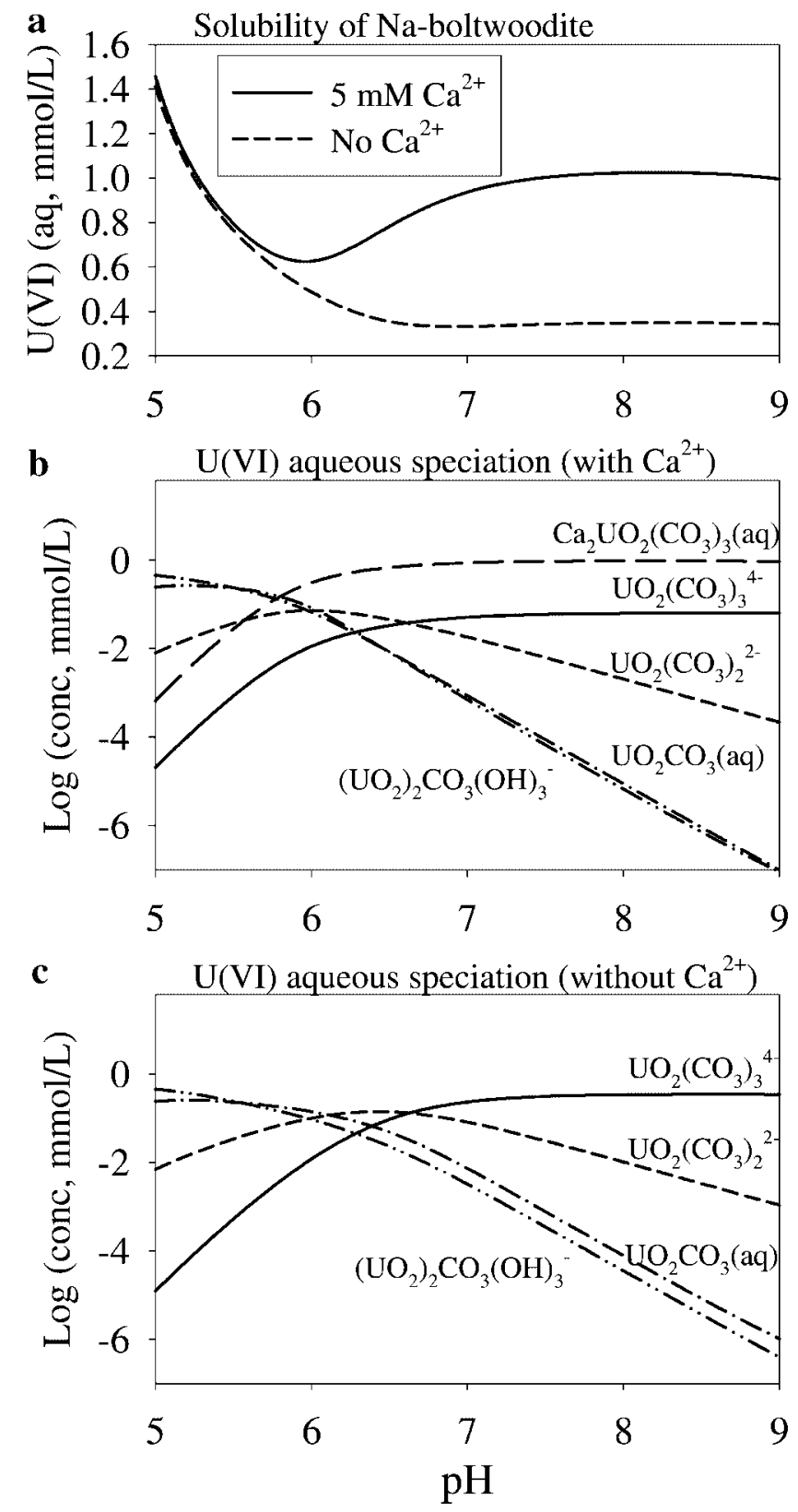

Figure 1. Calculated solubility of Na-boltwoodite in bicarbonate solutions with/ without calcium (plot a) and associated aqueous $\mathrm{U}(\mathrm{VI})$ speciation with calcium (plot b) and without calcium (plot c). Solutions contain $10 \mathrm{mmol} / \mathrm{L} \mathrm{NaHCO}_{3}, 10 \mathrm{mmol} / \mathrm{L}$ $\mathrm{Na}$-lactate, and $\mathrm{pH} 6.8$ buffered with $10 \mathrm{mmol} / \mathrm{L} \mathrm{Na-PIPES}$. The calcium solution also contains $5 \mathrm{mmol} / \mathrm{L} \mathrm{CaCl}_{2}$.

increase will also increase the rate of $\mathrm{U}(\mathrm{VI})$ dissolution (Liu et al., 2006b) and thus may enhance the overall rate of microbial reduction of solid phase U(VI). The overall effect of calcium on microbial reduction of solid phase U(VI) may depend on the contrasting effects of calcium on the rates of solid phase $\mathrm{U}(\mathrm{VI})$ dissolution and microbial reduction of dissolved U(VI).

Here we reported an investigation on the effects of calcium on the kinetics of dissolution and microbial reduction of a solid phase $\mathrm{U}(\mathrm{VI})$ using a representative DMRB (Shewanella oneidensis strain MR-1). Sodium boltwoodite $\left(\mathrm{NaUO}_{2} \mathrm{SiO}_{3} \mathrm{OH} \cdot 1.5 \mathrm{H}_{2} \mathrm{O}\right)$, which was found in the granitic lithic fragment of the contaminated sediments at the US Department of Energy (DOE) Hanford site (Catalano et al., 2004; Liu et al., 2004; McKinley et al., 2006; Wang et al., 2005), was used as a representative solid phase U(VI). Batch experiments with/without calcium were performed to evaluate the influence of calcium on the rates of Na-boltwoodite dissolution and microbial reduction. Calcium is a common groundwater component that is in equilibrium with calcite at the Hanford site. Laser-induced florescence spectroscopy (LIFS) and transmission electron microscopy (TEM) were used to provide insights on the dissolution and microbial reduction processes. Models of Na-boltwoodite dissolution, aqueous speciation, microbial reduction, and their coupling were used for data analysis.

\section{Experimental Procedures}

\section{Na-Boltwoodite}

The synthesis and characterization of Na-boltwoodite was described elsewhere (Ilton et al., 2006). Briefly uranyl acetate $\left[\mathrm{UO}_{2}\left(\mathrm{CH}_{3} \mathrm{COO}\right)_{2} \cdot 2 \mathrm{H}_{2} \mathrm{O}\right]$ was stoichiometrically mixed with sodium metasilicate $\left(\mathrm{Na}_{2} \mathrm{SiO}_{3} \cdot 9 \mathrm{H}_{2} \mathrm{O}\right)$ at room temperature in a chamber filled with argon. The suspension was adjusted to $\mathrm{pH} 10.5$ with $0.1 \mathrm{~mol} / \mathrm{L} \mathrm{NaOH}$, stirred at room temperature for $2 \mathrm{~h}$, and then moved out of the argon chamber and refluxed at $90^{\circ} \mathrm{C}$ for $24 \mathrm{~h}$. The solid in the suspension was collected by filtration, rinsed with boiling deionized (DI) water, vacuum-dried, and homogenized. The dried and homogenized solid was transferred into $125 \mathrm{~mL}$ Teflon Parr Bomb (model 4748, Parr Instrument Co., Moline, IL) and contacted with DI water at $150^{\circ} \mathrm{C}$ for 7 days. The solid was then filtered, rinsed with DI water, vacuum-dried, and stored at room temperature. The synthetic material has been characterized using various spectroscopic, microscopic, and wet-laboratory techniques (Ilton et al., 2006). The material has a BET surface area of $30.78 \mathrm{~m}^{2} / \mathrm{g}$ and a solubility $\left(\log K_{\mathrm{sp}}\right)$ of 5.85 .

\section{Microorganism and Culture Conditions}

Shewanella oneidensis strain MR-1 (Myers and Nealson, 1988) was used as a representative DMRB. Strain MR-1 was cultured with tryptic soy broth (TSB) $27.5 \mathrm{~g} / \mathrm{L}$ (Difco Laboratories, Detroit, MI) from frozen stock culture, which was kept in $40 \%$ glycerol at $-80^{\circ} \mathrm{C}$. The cells at mid- to latelog growth phase were harvested by centrifugation and washed twice with Na-PIPES (Na-1,4-piperazine- $N, N^{\prime}$-bis2-ethanesulfonic acid) buffer (10 mmol/L, pH 7). Cell density was determined with Acridine Orange Direct Count (AODC) method. The washed cells were re-suspended in PIPES buffer and purged with $\mathrm{O}_{2}$-free $\mathrm{N}_{2}$ for microbial reduction experiments. 


\section{Na-boltwoodite Dissolution and Microbial Reduction}

Na-boltwoodite dissolution and microbial reduction experiments were conducted using $125 \mathrm{~mL}$ glass serum bottles in a $97 \% \mathrm{Ar}$ and $3 \% \mathrm{H}_{2}$ atmosphere inside an anaerobic chamber (Coy Laboratory Products, Inc., Grass Lake, MI) that was equipped with a palladium catalyst for trace $\mathrm{O}_{2}$ treatment. Na-lactate $(10 \mathrm{mmol} / \mathrm{L})$ was used as the electron donor, Na-PIPES $(10 \mathrm{mmol} / \mathrm{L})$ as the $\mathrm{pH}$ buffer, and $\mathrm{Na}$ boltwoodite as the $\mathrm{U}(\mathrm{VI})$ source for electron acceptor. Anoxic solutions of Na-PIPES, Na-lactate, and $\mathrm{Na}$ boltwoodite powder were added to reactors with a final $\mathrm{U}(\mathrm{VI})$ concentrations of $4.4 \mathrm{mmol} / \mathrm{L}$. In select bottles, calcium $\left(5 \mathrm{mmol} / \mathrm{L} \mathrm{CaCl}_{2}\right)$ was provided to evaluate calcium effects on U(VI) dissolution and microbial reduction. The reactors were capped with thick butyl rubber stoppers and crimp sealed. Sodium bicarbonate $(10 \mathrm{mmol} / \mathrm{L})$ was added with a syringe and needle, and the solution $\mathrm{pH}$ was adjusted to 6.80 with $0.1 \mathrm{~mol} / \mathrm{L} \mathrm{HCl}$ or $\mathrm{NaOH}$. The Na-boltwoodite was first allowed to dissolve without bacteria to evaluate the influence of calcium on its solubility and dissolution kinetics. MR-1 cells were injected in the reactors with a syringe and needle when the dissolution of Na-boltwoodite was close to its solubility. The suspensions were gently shaken on a mechanical shaker at room temperature in the anaerobic chamber. At select times, $0.5 \mathrm{~mL}$ of solution was withdrawn from each reactor, filtered $(0.2 \mu \mathrm{m})$ and acidified ( $0.01 \mathrm{~mol} / \mathrm{L} \mathrm{HNO}_{3}$ final concentration) in the anaerobic chamber, and then analyzed for dissolved $\mathrm{U}(\mathrm{VI})$ with a Kinetic Phosphorescence Analyzer (KPA; Chemcheck Instruments, Richland, WA). Solution $\mathrm{pH}$ was measured using an Orion $250 \mathrm{~A}+\mathrm{pH}$ meter with a combination $\mathrm{pH} /$ temperature probe.

\section{Laser-Induced Fluorescence Spectroscopy}

Aqueous and solid phase samples, taken at select times from the reactors, were prepared in the anaerobic chamber, and analyzed by laser-induced fluorescence spectroscopy (LIFS) to monitor the changes of $\mathrm{U}(\mathrm{VI})$ speciation. The LIFS measurements were performed in a Cryo Industries RC-152 cryostat near liquid He-temperature $(5.5 \pm 1.0 \mathrm{~K})$. The fluorescence emission spectra were obtained by excitation at $415 \mathrm{~nm}$. The resulting fluorescence was collected at $75^{\circ}$ to the excitation beam by a $5 \mathrm{~cm}$ diameter $\mathrm{f} / 3$ fused silica lens and focused by a $5 \mathrm{~cm} \mathrm{f} / 4$ fused silica lens into the entrance slit of a $0.3 \mathrm{~m}$ focal length Acton SpectroPro 300i double monochromator spectrograph.

Time-resolved emission spectra were recorded using a thermoelectrically cooled Princeton Instruments PIMAX time-gated intensified CCD camera that was triggered by the delayed output of the laser pulse and controlled by the WinSpec data acquisition software. The light emitted by the sample was collected at $90^{\circ}$ by an $\mathrm{f} 1.5$ fused silica lens and detected by a Hamamatsu R928 photomultiplier tube (PMT) at wavelength between $490 \mathrm{~nm}$ and $550 \mathrm{~nm}$ after dispersing through a CVI R110 monochromator. The fluorescence intensity signal from the PMT was amplified and recorded with a Tektronics TDS 754A digital oscilloscope. Data analysis was performed using the IGOR, a commercial software, and the Globals program (Beechem et al., 1991).

\section{Transmission Electron Microscopy (TEM)}

Samples for high resolution TEM were prepared in an anaerobic glove box. Cell suspensions were washed three times with $0.1 \mathrm{~mol} / \mathrm{L} \mathrm{Na}$ cacodyalate buffer at $\mathrm{pH} 7.2$ followed by three washes with cold deionized water. The cells were pelleted, fixed in glutaraldehyde, dehydrated in series of $\mathrm{EtOH}$, and embedded in LR White resin. The polymerized blocks were anaerobically sectioned on a microtome, and thin sections were mounted on copper grids coated with formvar and carbon. The prepared samples were examined on JEOL 2010 TEM with an acceleration voltage of $200 \mathrm{kV}$. The elemental composition of cell-associated precipitates was determined using energy dispersive spectroscopy (EDS).

\section{Modeling}

Na-boltwoodite dissolution, aqueous speciation, microbial reduction of dissolved $\mathrm{U}(\mathrm{VI})$, and their coupling were modeled with a computer program: Geochemist Workbench 6.0 (Bethke, 2005). A thermodynamic database for aqueous $\mathrm{U}(\mathrm{VI})$ and other relevant species used in the calculations were described in Table I. Aqueous activity coefficients were calculated using the Davies equation.

\section{Results and Discussion}

\section{Dissolution}

The dissolution of Na-boltwoodite, as expressed by the increase of aqueous $\mathrm{U}(\mathrm{VI})$ concentration (Fig. 2), was initially fast, slowed with time, and reached equilibrium after about 5-7 days. Calcium significantly increased both the rate and extent of Na-boltwoodite dissolution (Fig. 2). The measured equilibrium concentrations were consistent with the Na-boltwoodite solubility with/without calcium (Fig. 1). The higher solubility in the calcium solution resulted from the formation of the ternary species of $\mathrm{Ca}_{2} \mathrm{UO}_{2}\left(\mathrm{CO}_{3}\right)_{3}(\mathrm{aq})$, which increased uranyl stability in aqueous phase. The kinetics of Na-boltwoodite dissolution was consistent with a following rate expression with parameters independently determined elsewhere (Liu et al., 2006b):

$$
\frac{\mathrm{d}[\mathrm{U}(\mathrm{VI})]_{\mathrm{aq}}}{\mathrm{dt}}=k A \rho_{\mathrm{b}} \frac{\left[\mathrm{HCO}_{3}^{-}\right]}{\mathrm{K}_{\mathrm{bc}}+\left[\mathrm{HCO}_{3}^{-}\right]}\left[1-\left(\frac{\mathrm{IAP}}{\mathrm{K}_{\mathrm{sp}}}\right)^{\mathrm{n}}\right]
$$

where $[\mathrm{U}(\mathrm{VI})]$ aq is the total aqueous $\mathrm{U}(\mathrm{VI})$ concentration, $k$ the rate constant $\left(2.05 \times 10^{-6} \mathrm{~mol} / \mathrm{m}^{2} / \mathrm{h}\right), A$ the $\mathrm{Na}-$ boltwoodite surface area $\left(30.8 \mathrm{~m}^{2} / \mathrm{g}\right), \rho_{\mathrm{b}}$ the Na-boltwoodite 
Table I. Equilibrium speciation reactions used in modelling.

\begin{tabular}{|c|c|c|}
\hline Speciation reaction & $\log K(I=0)$ & Source \\
\hline $\mathrm{UO}_{2}^{2+}+\mathrm{H}_{2} \mathrm{O}=\mathrm{UO}_{2} \mathrm{OH}^{+}+\mathrm{H}^{+}$ & -5.25 & Guillaumount et al., (2003) \\
\hline $\mathrm{UO}_{2}^{2+}+2 \mathrm{H}_{2} \mathrm{O}=\mathrm{UO}_{2}(\mathrm{OH})_{2}(\mathrm{aq})+2 \mathrm{H}^{+}$ & -12.15 & Guillaumount et al., (2003) \\
\hline $\mathrm{UO}_{2}^{2+}+3 \mathrm{H}_{2} \mathrm{O}=\mathrm{UO}_{2}(\mathrm{OH})_{3}^{-}+3 \mathrm{H}^{+}$ & -20.25 & Guillaumount et al. (2003) \\
\hline $\mathrm{UO}_{2}^{2+}+4 \mathrm{H}_{2} \mathrm{O}=\mathrm{UO}_{2}(\mathrm{OH})_{4}^{2-}+4 \mathrm{H}^{+}$ & -32.40 & Guillaumount et al. (2003) \\
\hline $2 \mathrm{UO}_{2}^{2+}+\mathrm{H}_{2} \mathrm{O}=\left(\mathrm{UO}_{2}\right)_{2} \mathrm{OH}^{3+}+\mathrm{H}^{+}$ & -2.70 & Guillaumount et al. (2003) \\
\hline $2 \mathrm{UO}_{2}^{2+}+2 \mathrm{H}_{2} \mathrm{O}=\left(\mathrm{UO}_{2}\right)_{2}(\mathrm{OH})_{2}^{2+}+2 \mathrm{H}^{+}$ & -5.62 & Guillaumount et al. (2003) \\
\hline $3 \mathrm{UO}_{2}^{2+}+4 \mathrm{H}_{2} \mathrm{O}=\left(\mathrm{UO}_{2}\right)_{3}(\mathrm{OH})_{4}^{2+}+4 \mathrm{H}^{+}$ & -11.90 & Guillaumount et al. (2003) \\
\hline $3 \mathrm{UO}_{2}^{2+}+5 \mathrm{H}_{2} \mathrm{O}=\left(\mathrm{UO}_{2}\right)_{3}(\mathrm{OH})_{5}^{+}+5 \mathrm{H}^{+}$ & -15.55 & Guillaumount et al. (2003) \\
\hline $3 \mathrm{UO}_{2}^{2+}+7 \mathrm{H}_{2} \mathrm{O}=\left(\mathrm{UO}_{2}\right)_{3}(\mathrm{OH})_{7}^{-}+7 \mathrm{H}^{+}$ & -32.20 & Guillaumount et al. (2003) \\
\hline $4 \mathrm{UO}_{2}^{2+}+7 \mathrm{H}_{2} \mathrm{O}=\left(\mathrm{UO}_{2}\right)_{4}(\mathrm{OH})_{7}^{+}+7 \mathrm{H}^{+}$ & -21.90 & Guillaumount et al. (2003) \\
\hline $\mathrm{UO}_{2}^{2+}+\mathrm{CO}_{3}^{2-}=\mathrm{UO}_{2} \mathrm{CO}_{3}(\mathrm{aq})$ & 9.94 & Guillaumount et al. (2003) \\
\hline $\mathrm{UO}_{2}^{2+}+2 \mathrm{CO}_{3}^{2-}=\mathrm{UO}_{2}\left(\mathrm{CO}_{3}\right)_{2}^{2-}$ & 16.61 & Guillaumount et al. (2003) \\
\hline $\mathrm{UO}_{2}^{2+}+3 \mathrm{CO}_{3}^{2-}=\mathrm{UO}_{2}\left(\mathrm{CO}_{3}\right)_{3}^{4-}$ & 21.84 & Guillaumount et al. (2003) \\
\hline $3 \mathrm{UO}_{2}^{2+}+6 \mathrm{CO}_{3}^{2-}=\left(\mathrm{UO}_{2}\right)_{3}\left(\mathrm{CO}_{3}\right)_{6}^{6-}$ & 54.00 & Guillaumount et al. (2003) \\
\hline $2 \mathrm{UO}_{2}^{2+}+\mathrm{CO}_{3}^{2-}+3 \mathrm{H}_{2} \mathrm{O}=\left(\mathrm{UO}_{2}\right)_{2} \mathrm{CO}_{3}(\mathrm{OH})_{3}^{-}+3 \mathrm{H}^{+}$ & -0.86 & Guillaumount et al. (2003) \\
\hline $3 \mathrm{UO}_{2}^{2+}+\mathrm{CO}_{3}^{2-}+3 \mathrm{H}_{2} \mathrm{O}=\left(\mathrm{UO}_{2}\right)_{3} \mathrm{O}(\mathrm{OH})_{2} \mathrm{HCO}_{3}^{+}+3 \mathrm{H}^{+}$ & 0.65 & Guillaumount et al. (2003) \\
\hline $2 \mathrm{Ca}^{2+}+\mathrm{UO}_{2}^{2+}+3 \mathrm{CO}_{3}^{2-}=\mathrm{Ca}_{2} \mathrm{UO}_{2}\left(\mathrm{CO}_{3}\right)_{3}(\mathrm{aq})$ & 29.80 & Kalmykov and Choppin (2000) \\
\hline $\mathrm{UO}_{2}^{2+}+\mathrm{Cl}^{-}=\mathrm{UO}_{2} \mathrm{Cl}^{+}$ & 0.17 & Guillaumount et al. (2003) \\
\hline $\mathrm{UO}_{2}^{2+}+2 \mathrm{Cl}^{-}=\mathrm{UO}_{2} \mathrm{Cl}_{2}(\mathrm{aq})$ & -1.10 & Guillaumount et al. (2003) \\
\hline $\mathrm{UO}_{2}^{2+}+\mathrm{H}_{4} \mathrm{SiO}_{4}=\mathrm{UO}_{2} \mathrm{H}_{3} \mathrm{SiO}_{4}^{+}+\mathrm{H}^{+}$ & -1.84 & Guillaumount et al. (2003) \\
\hline $\mathrm{CO}_{2}(\mathrm{~g})+\mathrm{H}_{2} \mathrm{O}=\mathrm{H}_{2} \mathrm{CO}_{3}$ & -1.47 & Guillaumount et al. (2003) \\
\hline $\mathrm{H}_{2} \mathrm{CO}_{3}=\mathrm{H}^{+}+\mathrm{HCO}_{3}^{-}$ & -6.35 & Guillaumount et al. (2003) \\
\hline $\mathrm{H}_{2} \mathrm{CO}_{3}=2 \mathrm{H}^{+}+\mathrm{CO}_{3}^{2-}$ & -16.68 & Guillaumount et al. (2003) \\
\hline $\mathrm{H}_{4} \mathrm{SiO}_{4}=\mathrm{H}^{+}+\mathrm{H}_{3} \mathrm{SiO}_{4}^{-}$ & -23.14 & Guillaumount et al. (2003) \\
\hline $\mathrm{H}_{4} \mathrm{SiO}_{4}=2 \mathrm{H}^{+}+\mathrm{H}_{2} \mathrm{SiO}_{4}^{2-}$ & -9.84 & Guillaumount et al. (2003) \\
\hline $\mathrm{Ca}^{2+}+\mathrm{CO}_{3}^{2-}=\mathrm{CaCO}_{3}(\mathrm{aq})$ & 2.48 & NIST (2001) \\
\hline $\mathrm{Ca}^{2+}+\mathrm{CO}_{3}^{2-}+\mathrm{H}^{+}=\mathrm{CaHCO}_{3}^{+}$ & 11.43 & NIST (2001) \\
\hline
\end{tabular}

concentration in suspension $(\mathrm{g} / \mathrm{L}), K_{\mathrm{bc}}$ the half-rate constant with respect to bicarbonate $\left(2.74 \times 10^{-3} \mathrm{~mol} / \mathrm{L}\right)$, IAP and $K_{\mathrm{sp}}$ the ion activity product and solubility constant $\left(\log K_{\mathrm{sp}}=5.85\right)$ for Na-boltwoodite, respectively; $n$ the

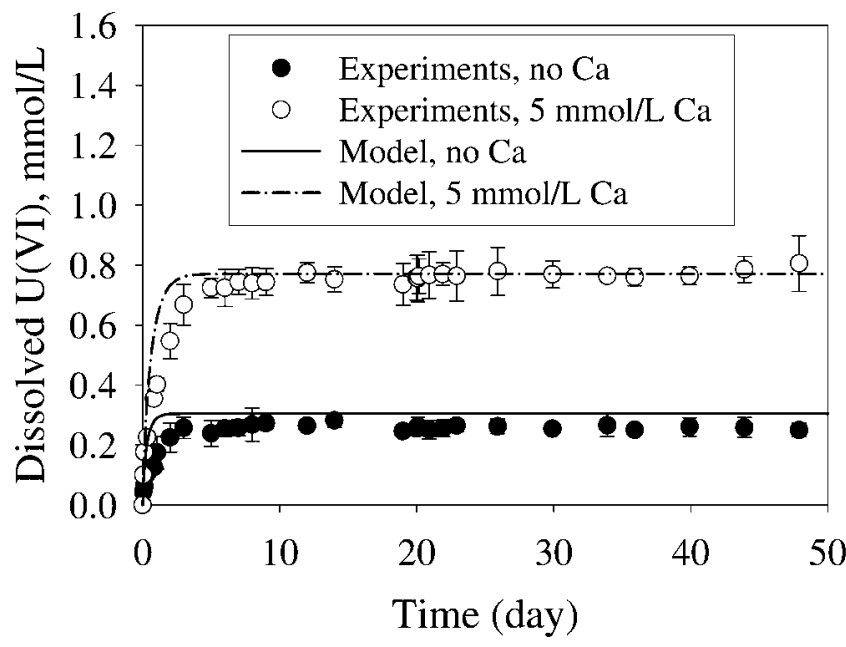

Figure 2. Dissolution kinetics of Na-boltwoodite in bicarbonate solutions with/ without calcium. Symbols and lines are experimental and modeling results, respectively. See text for model descriptions. Experimental conditions: $10 \mathrm{mmol} / \mathrm{L} \mathrm{Na}-\mathrm{HCO}_{3}$, $10 \mathrm{mmol} / \mathrm{L} \mathrm{Na}$-lactate, $\mathrm{pH} 6.8$ buffered with $10 \mathrm{mmol} / \mathrm{L} \mathrm{Na}$-PIPES, and $4.4 \mathrm{mmol} / \mathrm{L} \mathrm{Na}$ boltwoodite. The calcium suspension also contained $5 \mathrm{mmol} / \mathrm{L} \mathrm{CaCl}_{2}$. reaction order of nonlinearity $(0.2)$, and $\left[\mathrm{HCO}_{3}^{-}\right]$is the bicarbonate concentration $(\mathrm{mol} / \mathrm{L})$.

Model calculations (Fig. 2) were performed by coupling Na-boltwoodite dissolution (Eq. 1) and equilibrium speciation reactions (Table I). The same rate expression (Eq. 1) and constants were used to describe Na-boltwoodite dissolution in solutions with/without calcium except that species $\mathrm{Ca}_{2} \mathrm{UO}_{2}\left(\mathrm{CO}_{3}\right)_{3}(\mathrm{aq})$ was not considered in the solution without calcium. The effect of aqueous uranyl speciation (Table I) on the kinetic rate and extent was considered through the thermodynamic affinity term (i.e., $\left.\mathrm{IAP} / K_{\mathrm{sp}}\right)$ and in evaluation of bicarbonate concentration (i.e., $\left[\mathrm{HCO}_{3}^{-}\right]$) in Equation (1). The influence of lactate on $\mathrm{Ca}^{2+}$, and thus $\mathrm{U}(\mathrm{VI})$ speciation was not considered because of the weak aqueous complexation between $\mathrm{Ca}^{2+}$ and lactate (NIST, 2001) and excess $\mathrm{Ca}^{2+}$ was provided to complex with $\mathrm{U}(\mathrm{VI})$. The rate expression was characterized elsewhere in bicarbonate solutions in equilibrium with atmosphere $\mathrm{CO}_{2}$ (Liu et al., 2006b). This previously characterized rate expression slightly over-predicted, but closed to the measured rates of $\mathrm{U}(\mathrm{VI})$ dissolution in the first 7 days in both solutions with/without calcium, indicating that the rate expression (Eq. 1) was applicable for describing Na-boltwoodite dissolution kinetics in the $\mathrm{CO}_{2}(\mathrm{~g})$-closed system and the affinity term (IAP/ $K_{\mathrm{sp}}$ ) effectively described the effect of calcium-uranyl-carbonate speciation on the dissolution rate. The calculated dissolution extent in the calcium-bicarbonate solution quantitatively matched with 
the measured value, but slightly over-predicted the measured extent in the bicarbonate solution without calcium (Fig. 2). The over-prediction was considered within the experimental errors considering the standard deviation of Na-boltwoodite solubility product $\left(\log K_{\mathrm{sp}}=5.85 \pm 0.26\right)$ (Ilton et al., 2006).

\section{Microbial Reduction}

The addition of MR-1 in solutions without $\mathrm{Ca}^{2+}$ that had experienced 10 days of $\mathrm{Na}$-boltwoodite dissolution led to an immediate decrease in aqueous $\mathrm{U}(\mathrm{VI})$ concentrations (Fig. 3). The decrease of the aqueous U(VI) concentrations was fast within the first hour of cell addition, then stabilized,
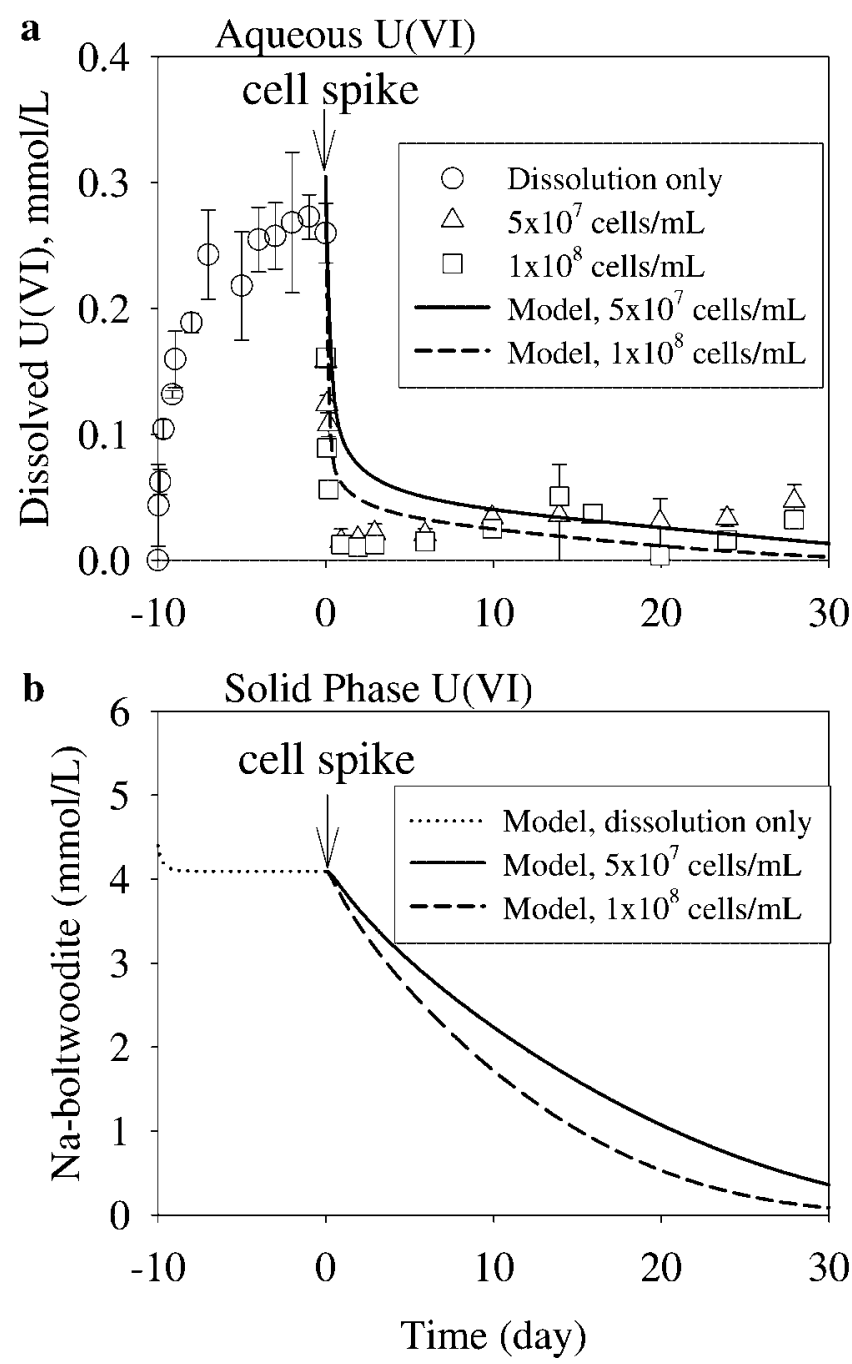

Figure 3. Concentrations of dissolved U(VI) (plot a) and residual solid phase $\mathrm{U}(\mathrm{VI})$ (plot b) resulting from Na-boltwoodite dissolution and microbial reduction in solutions without calcium. Symbols and lines are experimental and modeling results, respectively. Experimental conditions were the same as described in Figure 2. The cells were spiked after 10 days of dissolution with cell concentrations described in the figure legend. and showed slight increase with time at late time. The rate was slightly faster and aqueous $\mathrm{U}(\mathrm{VI})$ concentration stabilized at a lower level in the solution with a higher cell concentration $\left(1 \times 10^{8}\right.$ compared to $5 \times 10^{7}$ cells $\left./ \mathrm{mL}\right)$. The stabilization of aqueous U(VI) concentration was due to the re-supply of aqueous $\mathrm{U}(\mathrm{VI})$ from Na-boltwoodite dissolution, which apparently approached similar rates as the microbial reduction of dissolved $\mathrm{U}(\mathrm{VI})$ after $1 \mathrm{~h}$ of microbial activity. The low stabilized aqueous U(VI) concentrations after the first hour of bioreduction indicated that the dissolution kinetics of $\mathrm{Na}$-boltwoodite limited the rate of microbial reduction of $U(V I)$. The slight increase of aqueous $\mathrm{U}(\mathrm{VI})$ concentration at the late stage suggested that the rates of microbial activity decreased with time, probably reflecting decreasing cell viability with time in non-growth media (Liu et al., 2006a).

The decrease of aqueous U(VI) concentrations in solutions with calcium (Fig. 4) was slower than in solutions without calcium (Fig. 3$)$ under the same cell $\left(1 \times 10^{8}\right.$ cells $\left./ \mathrm{mL}\right)$ and total solid phase $\mathrm{U}(\mathrm{VI})$ concentrations, reflecting combined effects of the species $\mathrm{Ca}_{2} \mathrm{UO}_{2}\left(\mathrm{CO}_{3}\right)_{3}(\mathrm{aq})$ on inhibiting microbial reduction of dissolved $\mathrm{U}(\mathrm{VI})$ (Brooks et al., 2003) and enhancing U(VI) dissolution kinetics (Fig. 2). Increasing cell concentrations led to the expected fast decrease of aqueous $\mathrm{U}(\mathrm{VI})$ concentration. The decrease of aqueous $\mathrm{U}(\mathrm{VI})$ concentration was initially fast and then slowed with time because the rate of $\mathrm{Na}$-boltwoodite dissolution increased with decreasing aqueous $\mathrm{U}(\mathrm{VI})$ concentration as predicted from the thermodynamic affinity term in Equation (1). The results in Figures 3 and 4 clearly showed the effects of calcium on the $\mathrm{U}(\mathrm{VI})$ dissolution, microbial reduction, and their coupling on the aqueous $U(V I)$ concentration. The mechanism for the slower rates of microbial reduction in Ca-solutions was unclear, but it may have related to redox reaction driving force. The half redox potentials for the dominant $\mathrm{U}(\mathrm{VI})$ species $\left[\mathrm{UO}_{2}\left(\mathrm{CO}_{3}\right)_{2}^{2-}, \mathrm{UO}_{2}\left(\mathrm{CO}_{3}\right)_{3}^{4-}, \mathrm{Ca}_{2} \mathrm{UO}_{2}\left(\mathrm{CO}_{3}\right)_{3}(\mathrm{aq})\right.$, and Na-boltwoodite] in these solutions were calculated and listed in Table II. The redox potentials for species $\mathrm{UO}_{2}\left(\mathrm{CO}_{3}\right)_{2}^{2-}$ and $\mathrm{UO}_{2}\left(\mathrm{CO}_{3}\right)_{3}^{4-}$ are about $100 \mathrm{mV}$ higher than $\mathrm{Ca}_{2} \mathrm{UO}_{2}\left(\mathrm{CO}_{3}\right)_{3}(\mathrm{aq})$ under our experimental conditions, indicating that microbial reduction of $\mathrm{U}(\mathrm{VI})$ has a stronger thermodynamic driving force in solutions without $\mathrm{Ca}^{2+}$ than in solutions with $\mathrm{Ca}^{2+}$.

Dissolution and microbial reduction did not alter the spectral properties of the solid phase U(VI) in suspensions with/without calcium as indicated by LIFS analysis that showed the same spectra of the solid phase U(VI) before and after dissolution and microbial reduction (Fig. 5). The result is consistent with equilibrium speciation calculations (data not shown) that suggested no other solid phase U(VI) was saturated under the experimental conditions. Analysis of aqueous samples using the LIFS technique at liquid helium temperature revealed the characteristic spectral peaks of species $\mathrm{UO}_{2}\left(\mathrm{CO}_{3}\right)_{3}^{4-}$ (data not shown), as reported in (Wang et al., 2004), but found no obvious spectral differences in solutions with/without calcium. This is in contrast, for unknown reasons, with the previous reports 

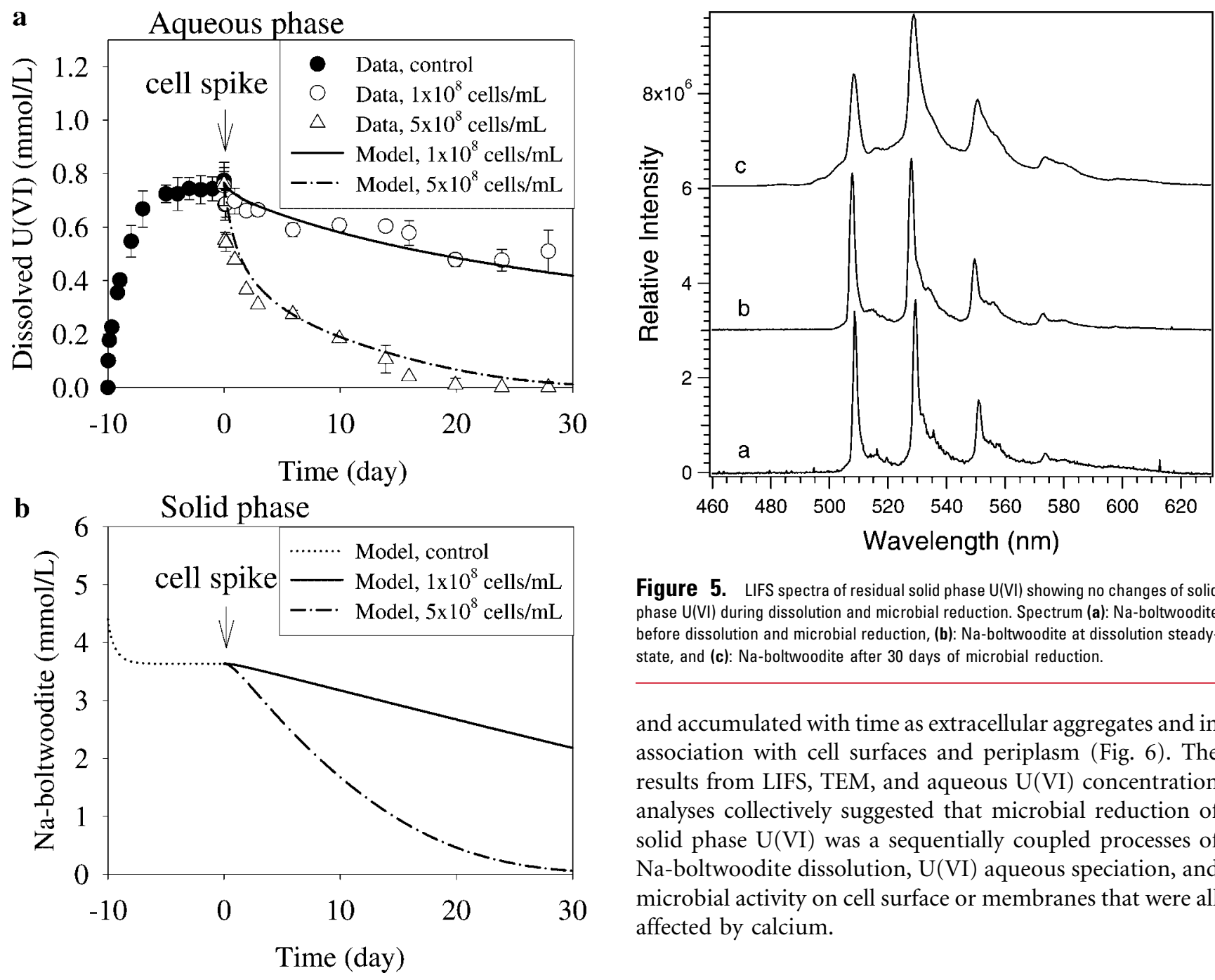

Figure 5. LIFS spectra of residual solid phase U(VI) showing no changes of solid phase U(VI) during dissolution and microbial reduction. Spectrum (a): Na-boltwoodite before dissolution and microbial reduction, (b): Na-boltwoodite at dissolution steadystate, and (c): Na-boltwoodite after 30 days of microbial reduction.

and accumulated with time as extracellular aggregates and in association with cell surfaces and periplasm (Fig. 6). The results from LIFS, TEM, and aqueous U(VI) concentration analyses collectively suggested that microbial reduction of solid phase $\mathrm{U}(\mathrm{VI})$ was a sequentially coupled processes of Na-boltwoodite dissolution, $\mathrm{U}(\mathrm{VI})$ aqueous speciation, and microbial activity on cell surface or membranes that were all affected by calcium.

Figure 4. Concentrations of dissolved U(VI) (plot a) and residual solid phase $\mathrm{U}(\mathrm{VI})$ (plot b) as a function of time during Na-boltwoodite dissolution and microbial reduction in solutions containing $5 \mathrm{mmol} / \mathrm{L}$ calcium. Symbols and lines are experimental and modeling results, respectively. Experimental conditions were the same as described in Figure 2 . The cells were spiked after 10 days of dissolution with cell concentrations described in the figure legends.

that solutions dominated with calcium-uranyl-carbonate species have different LIFS spectra from solutions dominated by uranyl-carbonate species (Dong et al., 2005; Wang et al., 2004). TEM analysis revealed that U(IV) precipitated

\section{Modeling of Microbial Reduction}

The dissolution and microbial reduction could be effectively described by coupling the dissolution kinetics (Eq. 1), equilibrium speciation reactions (Table I), and a nongrowth Monod-type rate with respect to aqueous $\mathrm{U}(\mathrm{VI})$ concentration,

$$
\frac{\mathrm{d}[\mathrm{U}(\mathrm{VI})]_{\mathrm{aq}}}{\mathrm{d} t}=-\frac{V_{m}[\mathrm{U}(\mathrm{VI})]_{\mathrm{aq}}}{K_{s}+[\mathrm{U}(\mathrm{VI})]_{\mathrm{aq}}} X
$$

Table II. Half redox potentials of select U(VI) species*

\begin{tabular}{|c|c|c|}
\hline Reaction & $E_{0}(\mathrm{~V})$ & $E(\mathrm{~V})$ \\
\hline $\mathrm{UO}_{2}\left(\mathrm{CO}_{3}\right)_{2}^{2-}+2 \mathrm{H}^{+}+2 \mathrm{e}^{-}=\mathrm{UO}_{2}(\mathrm{~s})+2 \mathrm{HCO}_{3}^{-}$ & 0.53 & 0.25 \\
\hline $\mathrm{UO}_{2}\left(\mathrm{CO}_{3}\right)_{3}^{4-}+3 \mathrm{H}^{+}+2 \mathrm{e}^{-}=\mathrm{UO}_{2}(\mathrm{~s})+3 \mathrm{HCO}_{3}^{-}$ & 0.68 & 0.26 \\
\hline $\mathrm{Ca}_{2} \mathrm{UO}_{2}\left(\mathrm{CO}_{3}\right)_{3}+3 \mathrm{H}^{+}+2 \mathrm{e}^{-}=\mathrm{UO}_{2}(\mathrm{~s})+2 \mathrm{Ca}^{2+}+3 \mathrm{HCO}_{3}^{-}$ & 0.45 & 0.16 \\
\hline $\mathrm{NaUO}_{2} \mathrm{Si}_{3} \mathrm{OH} \cdot 1.5 \mathrm{H}_{2} \mathrm{O}($ Na-boltwoodite $)+3 \mathrm{H}^{+}+2 \mathrm{e}^{-}=\mathrm{UO}_{2}(\mathrm{~s})+\mathrm{Na}^{+}+\mathrm{H}_{4} \mathrm{SiO}_{4}+1.5 \mathrm{H}_{2} \mathrm{O}$ & 0.58 & 0.12 \\
\hline
\end{tabular}

\footnotetext{
${ }^{*} E_{0}$ and $E$ are the redox potentials at the standard state and under our experimental conditions, respectively. The reaction constants in Table I and formation free energies for auxiliary species in reference (Guillaumount et al., 2003) were used to calculate $E_{0}$. Redox potential $E$ was calculated using $E_{0}$ and species concentrations of $10,5,30$, and $0.5 \mathrm{mmol} / \mathrm{L}$ for $\mathrm{HCO}_{3}^{-}, \mathrm{Ca}^{2+}, \mathrm{Na}^{+}$, and $\mathrm{H}_{4} \mathrm{SiO}_{4}$, respectively.
} 


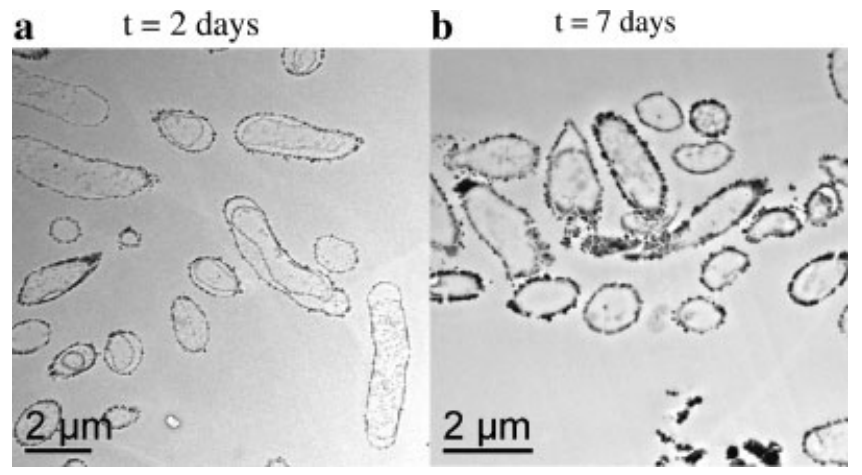

Figure 6. TEM images showing $\mathrm{UO}_{2}$ (black) on cell surfaces and in periplasm, and $\mathrm{UO}_{2}$ accumulation with time. Image samples were collected after 2 days (plot a) and 7 days (plot b) of microbial reduction. Only images from solutions containing $5 \mathrm{mmol} / \mathrm{L} \mathrm{CaCl}{ }_{2}$ were shown. Images from solutions without calcium were similar.

where $V_{\mathrm{m}}(\mathrm{mol} / \mathrm{cell} / \mathrm{h})$ is the maximum rate; $K_{\mathrm{s}}(\mathrm{mol} / \mathrm{L})$ the half-rate constant with respect to total aqueous $\mathrm{U}(\mathrm{VI})$, $[\mathrm{U}(\mathrm{VI})]_{\mathrm{aq}}$ the total aqueous $\mathrm{U}(\mathrm{VI})$ concentration $(\mathrm{mol} / \mathrm{L})$; and $X$ is the cell concentration (cell/L). This kinetic expression has been previously used to describe microbial reduction of aqueous $\mathrm{U}(\mathrm{VI})$ by a range of microorganisms including $S$. alga strain BrY (Truex et al., 1997), S. putrefaciens strain CN32 (Liu et al., 2002b), and Geobacter sulfurreducens (Roden and Scheibe 2005), and a sulfate reducing bacteria Desulfovibrio desulfuricans (ATCC7757) (Spear et al., 1999). The $V_{\mathrm{m}}$ and $K_{\mathrm{s}}$ in solutions with calcium were previously determined to be $4.23 \times 10^{-17} \mathrm{~mol} / \mathrm{cell} / \mathrm{h}$ and $3.7 \times 10^{-4} \mathrm{~mol} / \mathrm{L}$, respectively (Liu et al., 2006a). In solutions without calcium, parameter values of $V_{\mathrm{m}}=1.1 \times 10^{-15} \mathrm{~mol} / \mathrm{cell} / \mathrm{h}$ and $K_{\mathrm{s}}=3.7 \times 10^{-4} \mathrm{~mol} / \mathrm{L}$ that were determined for $S$. putrefaciens strain CN32 were used because the rates of bioreduction of aqueous $\mathrm{U}(\mathrm{VI})$ were similar for MR-1 and CN32 (Liu et al., 2002a).

The coupled model of the dissolution kinetics (Eq. 1), equilibrium speciation reactions (Table I), and microbial reduction (Eq. 2) provided reasonably well descriptions of the experimental results in solutions with/without calcium (Fig. 3a and 4a). The calculated solid phase U(VI) concentrations (Fig. $3 \mathrm{~b}$ and $4 \mathrm{~b}$ ) continuously decreased with time, resulting from the continuous dissolution of solid phase $\mathrm{U}(\mathrm{VI})$ and microbial reduction of dissolved $\mathrm{U}(\mathrm{VI})$. The decrease of solid phase $\mathrm{U}(\mathrm{VI})$ concentration in the calcium-solution was slower than in the calcium-free solution under the same cell concentration $\left(1 \times 10^{8}\right.$ cells/ $\mathrm{mL}$ ) despite the faster rate of Na-boltwoodite dissolution in the earlier solution (Fig. 2). This contrast resulted from the faster microbial reduction of dissolved $\mathrm{U}(\mathrm{VI})$ in the calcium-free solution, which decreased aqueous $\mathrm{U}(\mathrm{VI})$ concentration and drove the faster dissolution of the solid phase $\mathrm{U}(\mathrm{VI})$. The maximum rate constant ( $V_{\mathrm{m}}$ in Eq. 2 ) in calcium-free solutions was 26 times faster than in the calcium-solutions. However, if the calculated total (aqueous and solid) U(VI) concentrations as a function of time were fitted to a pseudo first-order rate model with respect to total $\mathrm{U}(\mathrm{VI})$ concentration, the first-order rate constant in the calcium-free solutions was only about five times faster than in the calcium-solutions under the same cell concentration $\left(1 \times 10^{8}\right.$ cells $\left./ \mathrm{mL}\right)$. This contrast resulted from the faster rate and higher extent of $\mathrm{Na}$-boltwoodite dissolution in the calcium-solutions, which mitigated the effect of a smaller rate constant on the microbial reduction kinetics (Eq. 2). The results clearly demonstrated the effect of solubility and dissolution kinetics of solid phase $\mathrm{U}(\mathrm{VI})$ on the overall rate of microbial reduction of solid phase $\mathrm{U}(\mathrm{VI})$.

\section{Implication}

This study demonstrated that calcium can significantly affect the rates of U(VI) dissolution, microbial reduction, and their coupling through aqueous $\mathrm{U}(\mathrm{VI})$ complexation reaction in bicarbonate solutions. Calcium is a common chemical component in groundwater and has a concentration range of $0.5-50 \mathrm{mmol} / \mathrm{L}$ and a medium of about $5 \mathrm{mmol} / \mathrm{L}$ in the Hanford porewater and groundwater (Serne et al., 2002). Speciation calculations and spectroscopic analyses indicated that either $\mathrm{UO}_{2}\left(\mathrm{CO}_{3}\right)_{3}^{4-}$ or $\mathrm{Ca}_{2} \mathrm{UO}_{2}\left(\mathrm{CO}_{3}\right)_{3}$ could dominate the aqueous $\mathrm{U}(\mathrm{VI})$ speciation depending on the chemical composition, $\mathrm{pH}$, and calcium concentration in the Hanford pore and groundwaters (Dong et al., 2005; Wang et al., 2004). The overall rates of microbial reduction of solid phase $\mathrm{U}(\mathrm{VI})$ are therefore expected to be variable in response to $\mathrm{U}(\mathrm{VI})$ aqueous speciation changes from $\mathrm{UO}_{2}\left(\mathrm{CO}_{3}\right)_{3}^{4-}-$ to $\mathrm{Ca}_{2} \mathrm{UO}_{2}\left(\mathrm{CO}_{3}\right)_{3}$-dominated solutions.

This study also demonstrated that aqueous $\mathrm{U}(\mathrm{VI})$ concentration was a complex function of $\mathrm{U}(\mathrm{VI})$ aqueous and solid phase geochemistry and microbial activity. The apparent rate of microbial reduction of $\mathrm{U}(\mathrm{VI})$ in terms of the decrease of aqueous U(VI) concentration was significantly slower than the intrinsic rate of microbial activity because of the continuous release of $\mathrm{U}(\mathrm{VI})$ from solid to aqueous phase. The reaction half-life of bioreduction of dissolved U(VI) by DMRB is typically at a scale of hours in pure cultures determined in laboratory experiments (Liu et al., 2002b; Roden and Scheibe, 2005; Spear et al., 1999; Truex et al., 1997), but increases to days and weeks in sediments with stimulated bacterial activities (Abdelouas et al., 1998; Finneran et al., 2002). While various mechanisms may explain such rate differences including cell types and physiological states, solution chemical compositions, and growth and non-growth media, this investigation highlights the importance of aqueous and solid phase U(VI) geochemistry in controlling the apparent rate of microbial reduction of aqueous $\mathrm{U}(\mathrm{VI})$ in subsurface sediments. Accurate prediction of the fate and transport of U(VI) during microbial reduction requires coupled models of geochemical and microbial processes.

This research was supported by the U.S. Department of Energy (DOE), Office of Biological and Environmental Research (OBER) 
through the Environmental Remediation Science Program (ERSP). Part of this research was performed in Environmental Molecular Science Laboratory (EMSL), a national scientific user facility sponsored by the Department of Energy's Office of Biological and Environmental Research and located at Pacific Northwest National Laboratory (PNNL). PNNL is operated for the DOE by Battelle Memorial Institute under Contract DE-AC05-76RLO 1830.

\section{References}

Abdelouas A, Lu Y, Lutze W, Nuttall EH. 1998. Reduction of U(VI) to $\mathrm{U}(\mathrm{IV})$ by indigenous bacteria in contaminated ground water. J Contam Hydrol 35:217-233.

Beechem JM, Gratton E, Mantulin WW. 1991. Globals Unlimited. UIUC Publication. Urbana, IL.

Bernhard G, Geipel G, Brendler V, Nitsche H. 1996. Speciation of uranium in seepage waters of a mine tailing pile studied by time-resolved laserinduced fluorescence spectroscopy (TRLFS). Radiochim Acta 74:87-91.

Bernhard G, Geipel G, Reich T, Brendler V, Amayri S, Nitsche H. 2001. Uranyl(VI) carbonate complex formation: Validation of the $\mathrm{Ca}_{2} \mathrm{UO}_{2}\left(\mathrm{CO}_{3}\right)_{3}(\mathrm{aq})$ species. Radiochim Acta 89:511-518.

Bethke CM. 2005. Geochemist Workbench Release 6.0. University of Illinois. Urbana, Champaign.

Brooks SC, Fredrickson JKSLC, Kennedy DW, Zachara JM, Flymale AE, Kelly SD, Kemner KM, Fendorf S. 2003. Inhibition of bacterial U(VI) reduction by calcium. Environ Sci Technol 37:1850-1858.

Catalano JG, Heald SM, Zachara JM, Brown GEJ. 2004. Spectroscopic and diffraction study of uranium speciation in contaminated Vadose zone sediments from the Hanford site, Washington. Environ Sci Tech sol 38:2822-2828.

Dong W, Ball WP, Liu C, Wang Z, Stone AT, Bai J, Zachara JM. 2005. Influence of calcite and dissolved calcium on $\mathrm{U}(\mathrm{VI})$ sorption to a Hanford subsurface sediment. Environ Sci Technol 39:7949-7955.

Finneran KT, Anderson RT, Nevin KP, Lovley DR. 2002. Potential for bioremediation of uranium-contaminated aquifers with microbial U(VI) reduction. Soil Sediment Contam 11(3):339-357.

Guillaumount R, Fanghänet T, Neck V, Fuger J, Palmer DA, Grenthe I, Rand MH. 2003. Update on the Chemical Thermodynamics of Uranium, Neptunium, Plutonium, Americium and Technetium. Amsterdam: Elsevier B.V. Amsterdam, The Netherlands.

Ilton ES, Liu C, Yantansee W, Wang Z, Moore D, Felmy A, Zachara JM. 2006. The dissolution of synthetic Na-boltwoodite in sodium carbonate solutions. Geochim Cosmochim Acta 70:4836-4849.

Kalmykov SN, Choppin GR. 2000. Mixed $\mathrm{Ca}^{2+} / \mathrm{UO}_{2}^{2+} / \mathrm{CO}_{3}^{2-}$ complex formation at different ionic strengths. Radiochim Acta 88:603-606.

Liu C, Gorby YA, Zachara JM, Fredrickson JK, Brown CF. 2002a. Reduction kinetics of $\mathrm{Fe}(\mathrm{III}), \mathrm{Co}(\mathrm{III}), \mathrm{U}(\mathrm{VI}), \mathrm{Cr}(\mathrm{VI})$, and $\mathrm{Tc}(\mathrm{VII})$ in cultures of dissimilatory metal reducing bacteria. Biotechnol Bioeng 80(6):637649.

Liu C, Zachara JM, Fredrickson JK, Kennedy DW, Dohnalkova A. 2002b. Modeling the inhibition of the bacterial reduction of $\mathrm{U}(\mathrm{VI})$ by $\beta$ $\mathrm{MnO}_{2(\mathrm{~s})}$. Environ Sci Technol 36:1452-1459.

Liu C, Zachara JM, Qafoku O, McKinley JP, Heald SM, Wang Z. 2004. Dissolution of uranyl microprecipitates from subsurface sediments at Hanford site, USA. Geochim Cosmochim Acta 68(22):4519-4537.

Liu C, Jeon B-H, Zachara JM, Wang Z, Dohnalkova A, Fredrickson JK. 2006a. Kinetics of microbial reduction of solid phase U(VI). Environ Sci Technol 40:6290-6296.

Liu C, Zachara JM, Yantansee W, Majors PD, McKinley JP. 2006b. Microscopic reactive diffusion of uranium in the contaminated sediments at Hanford, USA. Water Resour Res 42:W12420 doi:10.1029/ 2006WR005031.

Lovley DR, Phillips EJ, Gorby YA, Landa E. 1991. Microbial uranium reduction. Nature 350:413-416.

McKinley JP, Zachara JM, Liu C, Heald SM. 2006. Microscale controls on the fate of contaminant uranium in the Vadose zone, Hanford site, Washington. Geochim Cosmochim Acta 70:1873-1887.

Myers CR, Nealson KH. 1988. Bacterial manganese reduction and growth with manganese oxide as the sole electron acceptor. Science 240:13191321.

NIST. 2001. Critically Selected Stability Constants of Metal Complexes Database, Version 6.0 for Windows. US Department of Commerce Gaithersburg, MD

Roden EE, Scheibe TD. 2005. Conceptual and numerical model of uranium(VI) reductive immobilization in fractured subsurface sediments. Chemosphere 59:617-628.

Serne RJ, Lindenmeirer CW, Kutnyakov IV, Last GV, Lindberg MJ, Baum SR, Gee GW, Clayton RE, Geiszler KN, Schaef HT. et al. 2002. Characterization of Vadose Zone Sediment: Borehole 299-E33-45Near Tank B-102 in the B-BX-BY Waste Management Area. Pacific Northwest National Laboratory, Richland, WA. Report nr PNNL14083.

Spear JR, Figueroa LA, Honeyman BD. 1999. Modeling the removal of uranium $\mathrm{U}(\mathrm{VI})$ from aqueous solutions in the presence of sulfate reducing bacteria. Environ Sci Technol 33:2667-2675.

Truex MJ, Peyton BM, Valentine NB, Gorby YA. 1997. Kinetics of U(VI) reduction by a dissimilatory $\mathrm{Fe}(\mathrm{III})$-reducing bacterium under nongrowth conditions. Biotechnol Bioeng 55:490-496.

Wang Z, Zachara JM, Yantansee W, Gassman PL, Liu C, Joly AG. 2004. Cryogenic laser induced fluorescence characterization of $\mathrm{U}(\mathrm{VI})$ in Hanford Vadose zone pore waters. Environ Sci Technol 38:55915597.

Wang Z, Zachara JM, Gassman PL, Liu C, Qafoku O, Catalano JG. 2005. Fluorescence spectroscopy of $\mathrm{U}(\mathrm{VI})$-silicate and $\mathrm{U}(\mathrm{VI})$-contaminated Hanford sediment. Geochim Cosmochim Acta 69:1391-1403. 